\title{
Z výzkumu společného vzdělávání v mateřských školách - podněty pro tvůrce vzdělávací politiky ${ }^{1}$
}

\author{
Helena Hejlová, Anna Tomková
}

\begin{abstract}
Abstrakt: Výzkum sledoval, k jakým zmènám v pedagogických procesech a jejich podminkách docházi v mateřské škole po zmènè spojené súpravami Rámcového vzdèlávacího programu pro předškolni vzdèláváni se zavádèním společného vzdèláváni do škol. Cíle zpracováni výzkumného šetrení pro potreby vzdèlávaci politiky vymezujeme ve dvou aspektech: (1) Strukturovat data do klícových kategorii tematizujicich zkušenosti, názory a predstavy pedagogů MŠ vázané na společné vzdèláváni. (2) V interpretačni úrovni vyzdvihnout oblasti podstatné pro dobrý průběh společného vzděláváni v MŠ. Teoretickým východiskem se stala koherence mezi hodnotami osobnostnè rozvíjejícího prístupu $k$ vedeni ditète $v$ MŠ a mezi hodnotami společného vzdèláváni. Metodou sbèru dat byl polostrukturovaný rozhovor. Vzorek tvorilo $10 \mathrm{MŠ}$ z Prahy a $10 \mathrm{MŠ} z$ Jihočeského kraje. Data byla zpracována do př́padových studii jednotlivých škol a následnè do hromadné studie. Výsledky jsou strukturovány do čtyř témat: (1) podminky v rovině názorů dotazovaných pedagogù MŠ; (2) podminky v rovině vnějǔich okolností práce $M S ̌$ jako instituce; (3) pedagogické procesy: zmèna jejich organizace, organizace třid/skupin, koncepce práce, péče o klima, povinné predškolni vzdèlávání. (4) Do modelu MŠ implementujici společné vzdèláváni. Závěry se týkaji podminek, které instituce, jako je MŠ, potrebuje pro společné vzděláváni. Strukturujeme je do pèti oblasti doporučeni pro vzdèlávaci politiku: (1) podpora orientace na osobnostně rozvijejici prístup prí vzděláváni dítète $v$ kurikulárnich dokumentech; (2) vzdèláváni pedagogických pracovniku; (3) počet dèti vázaný na počet osob, které o ně mohou pečovat a rozvijet je; (4) spolupráce MŠ s poradenskými pracovišti mimo školu; (5) podpora rodin, zvláštěo znevýhodněných.
\end{abstract}

Klícová slova: predškolni vzděláváni, osobnostně rozvijejici prìstup ke vzděláváni, společné vzdèláváni, pedagogické procesy, kvalitativni výzkum

Předkládaná výzkumná zpráva shr- dagogických procesů v mateřských škonuje a interpretuje výsledky šetření pe- lách. Sběr dat byl zaměřen na zkušenosti

\footnotetext{
${ }^{1}$ Tento text vznikl v rámci projektu IPs APIV A „Společné vzdělávání a podpora škol krok za krokem - Implementace Akčního plánu inkluzivního vzdělávání - metodická podpora“, CZ.02.3.61/0.0/0.0/16_020/0004410 OPVV, který je spolufinancován z fondů ESF. Na sběru dat a zpracování kazuistik se podílely rovněž Mgr. V. Bačová, Mgr. M. Najmonová, Ph.D., PhDr. J. Novotná a doc. PhDr. M. Vítečková, Ph.D.
} 
pedagogů $s$ jejich organizací, řízením, plánováním, ale také s řešením situací, které při nich typicky vznikají, a na vnímání podporujících a limitujících podmínek. Proběhl v rozmezí od října 2018 do záŕí 2020. Zpráva se řídí dvěma cíli: (1) Strukturovat data do klíčových kategorií tematizujících zkušenosti, názory a představy pedagogů $M S ̌$ vázané na společné vzdělávání. (2) V interpretační úrovni vyzdvihnout oblasti podmínek podstatných pro dobrý průběh společného vzdělávání v mateřské škole.

\section{TeORETICKÉ ASPEKTY}

\section{VÝZKUMNÉHO ŠETŘENÍ}

$\mathrm{Z}$ pohledu instituce, kterou je mateřská škola (dále MŠ), je společné vzdělávání (dále $S V$ ), jehož součástí je inkluzivní př́stup ke vzdělávání, prohloubením osobnostně rozvíjejícího přístupu při péči o dítě a jeho vedení. Tato teze je klíčovou teoretickou oporou pro referované výzkumné šetření.

Osobnostně rozvíjející model vzdělávání do kontextu pedagogického myšlení uváděl od 90. let minulého století Z. Helus (2009) a do předškolního vzdělávání jej rozpracovávala zejména E. Opravilová (2013). Helus (2012) si všímá širšího společenského a antropologického kontextu tohoto modelu. Osobnostně rozvíjející přístup ve vzdělávání znamená vnímat člověka, dítě, jako celistvou bytost, která se proměňuje svým vlastním vývojem ve svých životních podmínkách. Inspiračními zdroji je myšlení o člověku, které z his- torických zkušeností i z poznatků o lidské podstatě předpokládá, že člověk to lidské musí stále, v každé své životní situovanosti vybojovávat, objevovat a kultivovat. Proto je tak podstatný vliv mikro-, mezo- i makroprostředí, a to zejména v dětském věku, který je výrazně otevřen světu a jeho poznávání prožíváním i promýšlením. Úkolem výchovy je proto především vytvářet vhodné podmínky, které umožní dítěti plný rozvoj jeho sil, a současně ukazovat, jak překonávat nebezpečí redukcionismu (Helus, 2009) neboli stísnění možností projevit své bytostné síly, to na jedné straně. Na straně druhé ukazovat, jak se upozadit při respektování druhých lidí, neprosazovat sebe na úkor druhých, respektovat pravidla spolužití s druhými.

$\mathrm{V}$ těchto základních aspektech výchovy $\mathrm{v}$ konceptu osobnostně rozvíjejícího př́stupu $\mathrm{k}$ výchově dítěte se odráží i respektování potřeby dítěte být vedeno a vyvedeno $\mathrm{z}$ dětství postupným přebíráním odpovědnosti za vlastní rozhodování. Aby bylo možno těchto cílů dosáhnout, je základní podmínkou každé instituce pečující o dítě jeho bezpodmínečné přijetí a důvěra $\mathrm{v}$ jeho lidské nastavení (Opravilová, 2013). Další podmínkou jsou znalosti o dítěti a specifice dětství. Pedagogové MŠ jsou vzděláváni, aby si pěstovali vědomí, že dítě se mění věkem a nabýváním zkušeností a že mu má být pomoženo, aby tyto proměny směřovaly $\mathrm{k}$ nabývání identitního směřování osobnosti, i když $\mathrm{k}$ němu dochází posléze až na prahu dospělosti. Jsou jim předávány znalosti 
o tom, že dítě se v tomto věkovém období vyvíjí nerovnoměrně co do jednotlivých psychických procesů, motorických dovedností, schopností kontrolovat své emoce apod., že se vyvíjí skokově, že biologický věk nemusí vždy odpovídat věku mentálnímu a že toto vše je specifikou dětství, se kterou je třeba počítat při organizaci a řízení pedagogických procesů $\mathrm{v}$ instituci, kde žijí děti pohromadě. Helus (2012) tento př́stup nazval pedagogikou obratu. Měl tím na mysli takovou pedagogiku, která slouží člověku $\mathrm{v}$ jeho cestě za vyššími kvalitami bytí, i když, dodejme, se nedají přesně vymezovat ani pro jednotlivce, ani pro společenství.

Pro vztažný rámec našeho výzkumného šetření je podstatná souvislost s výzvou ke společnému vzdělávání, která je už nedílnou součástí mezinárodních i národních školsko-politických dokumentů. Koncept společného vzdělávání chápeme jako vytváření podmínek pro vzdělávání všech dětí tak, aby mohly dosáhnout plného rozvoje své osobnosti. Řídí se principem rovnosti a požadavkem nediskriminace. „Je to idea nediskriminace a idea naplnění potencí lidskosti cestou kvalitního, tj. obohacujícího vzdělávání, které umožní jedinci orientaci ve světě, v druhých i v sobě a které je současně prosociálně zaměřeno, vyjádřeno tezí umět žít s druhými" (Tomková \& Hejlová, 2018, s. 250). Zcitlivění vůči těmto idejím přibližně od osmdesátých let 20. století (Lang \& Berberichová, 1998) vedlo $\mathrm{k}$ výzvě pohlížet na lidi se znevý- hodněním nikoliv jako na ty, kteří něco nemohou, neumí nebo nemohou umět, ale jako na ty, kteří vidí svět jinak, ale stejně jako ostatní jsou plnohodnotnými osobnostmi. Postupně zaznívá poznání, že lidé tvoří dynamické množství variant životních projevů a pohledů. A na to musí v prvé řadě reagovat výchova a vzdělávací instituce. Opět je tak argumentováno přijetí každého a důvěra v jeho lidské potenciality jako základ pro jednání s dítětem při jeho výchovném a vzdělávacím vedení.

Náprava diskriminace, která je $\mathrm{v}$ současnosti už alespoň v ideové rovině překonaným pohledem na znevýhodněné jedince i skupiny, vedla $\mathrm{k}$ vyjádření požadavku na jejich začlenění do vzdělávání se všemi v pojmu inkluzivní vzdělávání. Šumníková \& Květoňová (2019) s odvoláním na výzkumná šetření a speciálněpedagogické prrístupy $\mathrm{k}$ výchově připomínají zásadní argument pro začleňování dětí se znevýhodněním mezi ostatní děti. Týká se právě osobnostně rozvíjejícího modelu jako přístupu, který ze své podstaty přijímá všechny děti jako potenciální, tedy postupně se rozvíjející osobnosti. Speciálněpedagogický argument pro společné vzdělávání a inkluzi dětí s překážkami při běžných, rozširíených, obecně zažitých způsobech výuky spočívá v přesvědčení, že různé typy omezení, zejména smyslového nebo pohybového, nemusí nutně ovlivnit celý průběh vývoje osobnosti, nemusí osobnost přetvářet nebo bránit jejímu plnému rozvoji. Centrální jádro osobnosti, tedy zaměřenost, schopnosti, 
temperament a charakter, je ovlivňováno mnohem více sociálními vztahy než určitým druhem znevýhodnění a stupněm deprivace. Zprostř̌edkování světa se děje více přes sociální vztahy, které se odrážejí při utváření osobnosti ve vnitřních vztazích jedince ke světu, druhým, sobě samému. Právo na učení a na vztahy, tedy sociálně emocionální aspekt vzdělávání zdůrazňují ve své práci také Lang a Berberichová (1998). Tento argument můžeme chápat jako zásadní z hlediska nároku každého na rozvoj jeho lidských potencialit a naplňování principu rovnosti v přístupu ke vzdělávání. Předpokladem je jiná organizace učení podmiňovaná pestrostí metod a vzdělávacích postupů, která musí být $\mathrm{v}$ repertoáru každého učitele. Je zřejmé, že pro kognitivní učení je třeba respektovat speciálnost potřeb různých dětí. Vytváření výkonnostně podobných skupin může být jednou z cest. Stejně tak je ale, a zvláště v předškolním věku, silný aspekt sociálního učení, tedy výchovy $\mathrm{v}$ užším slova smyslu, výchovy hodnotové a etické, spolužití. Lang a Berberichová (tamtéž) zdůrazňují, že pro rozvoj osobnosti dětí se speciálními vzdělávacími potřebami (dále SVP) je dobré setkávat se $s$ různými reakcemi $\mathrm{v}$ širší dětské komunitě než jen s podobně reagujícími dětmi v důsledku obdobných vzdělávacích potřeb. Pro děti, které nemají SVP, jen potřeby vlastního zrání a svých psychických mocností, je užitečné vidět, že svět může být nahlížen i jinak, nikoli omezeně, ale právě jinak. $\mathrm{V}$ tom je jeden z klíčových významů sociálního učení pro rozvoj osobnosti dítěte
Základním předpokladem pro realizaci inkluzivních vzdělávacích strategií jsou ale přesvědčení, hodnoty a postoje učitelů a dalších profesí, které jsou jim ve škole i mimo ni nápomocny. A také jejich zkušenosti a znalosti. Mezi ně patří nejen znalosti různorodých metod a organizačních forem, ale i znalosti obecnějších typů překážek, které mohou při učení nastávat. Pro tento druh profesních znalostí pedagog potřebuje včasnou a adresnou informaci od profesí, které se jimi cíleně zabývají - zejména od speciálních pedagogů a psychologů (Tomková et al., 2020). To vyžaduje jak typizaci, tak individualizaci ve smyslu vztahu obecného a zvláštního. Aniž by se opomíjela potřeba vnímat a prijímat každé jednotlivé dítě právě jako dítě, je užitečné porozumět obecným projevům konkrétního znevýhodnění jako jednomu z aspektů vzniku možných překážek $\mathrm{v}$ učení. $\mathrm{V}$ inkluzivních vzdělávacích strategiích a postupech se stávají klíčovým výrazem pro didaktickou transformaci obsahů různého charakteru. Ačkoli jsou významné zejména pro kognitivní učení, nelze pominout, že více nebo méně zasahují i do emocionálního a sociálního učení, taktéž senzomotorického a psychomotorického.

Co to znamená, naznačují Stinkenová-Rösnerová a její kolegové (2020). Překážky $\mathrm{v}$ učení vznikají vzájemným působením dítěte a učebního prostředí, má být na ně pohlíženo jako na výsledek této interakce. Nelze je tedy považovat primárně za něco, co přináší dítě samo, a co tedy má být odstraněno nebo adap- 
továno, př́ípadně respektováno. Proto má být vytvářeno prostředí inkluzivní, pro něž autoři navrhují tři kroky. I když nad nimi uvažují z hlediska užší otázky, jak realizovat pro naplnění požadavků inkluze osvojování si obsahů přírodovědného vzdělávání a nabývání príríodovědné gramotnosti, shledáváme je natolik obecně platnými, že je můžeme aplikovat i do oblasti předškolní pedagogiky. Prvním krokem je přijetí rozmanitosti, to je záležitost postojová. Souběžně jde o aktuální rozpoznávání rozmanitosti v dané dětské skupině. Tím se vytvoří prostor pro uvažování nad možnými různými postupy pro rozvíjení různých dětí. Druhým krokem je rozpoznání překážek, které by některé děti mohly mít, kdyby se věnovaly stejným činnostem stejnými postupy jako většina skupiny. To předpokládá, že pedagog se musí soustředit na toho, kdo se učí, nejen na to, co učit a jak. Rozpoznat, jestli překážky mohou být na úrovni kognitivní, jazykové, afektivní, fyzické apod., je východiskem pro úvahy nad nabídkou činností a postupů. Tyto dva kroky jsou předpokladem pro třetí krok, kterým je umožnění účasti. To předpokládá širokou nabídku obsahů, aktivit a motivačních pobídek, aby každé dítě mohlo naplňovat své zájmy, poznávat své možnosti a rozvíjet se, a to i ve smyslu získávání gramotností nutných pro život.

Tyto a další poznatky ovlivňují také vzdělávací politiku. $\mathrm{Na}$ evropské úrovni doporučuje Evropská komise v dokumentu Toolkit for inklusive early childhood education and care (2020) vytvářet státní systém péče o různorodé děti zahrnující konkrétní opatření a náměty ke zlepšení na národní, regionální i lokální úrovni. Za nejvýznamnější faktor kvality péče o dítě je považován vedle rodiny tým školy. Je proto doporučováno, aby byli pedagogové průběžně vzděláváni, aby jim byla poskytována odborná podpora a aby bylo pečováno o jejich dobré pracovní podmínky. V České republice bylo reálně zahájeno systémové zavádění společného vzdělávání do škol, včetně škol mateřských, zákonem č. 82/2015 Sb., kterým se změnil zákon č. 561/2004 Sb., o předškolním, základním, středním, vyšším odborném a jiném vzdělávání (školský zákon). Rámcový vzdělávací program pro předškolní vzdělávání (dále RVP PV) deklaruje, že „vychází ve své základní koncepci z respektování individuálních potřeb a možností dítěte" $(2018$, s. 35), a požaduje, ve shodě s konceptem osobnostně rozvíjejícího přístupu ve vzdělání a výchově, aby ve škole byly vytvářeny optimální podmínky $\mathrm{k}$ rozvoji osobnosti každého dítěte. Klade na MŠ nároky na vysokou kvalitu podmínek předškolního vzdělávání (materiální, životospráva, psychosociální, organizační, řízení MŠ, personální a pedagogické, spoluúčast rodičů). Také významný dokument Strategie vzdělávací politiky 2030+ formuluje požadavek „snížit nerovnosti v př́stupu ke kvalitnímu vzdělávání a umožnit maximální rozvoj potenciálu dětí, žáků a studentü“ (2020, s. 29), kterým se realizují ideje společného vzdělávání. Dokument zdů- 
razňuje, že pro předškolní vzdělávání je „vhodné, aby bylo včasně zahájeno, zaměřené na rozvoj kompetencí důležitých pro úspěch $\mathrm{v}$ dalším stupni vzdělávání a na rozvoj sociálních dovedností dětí" (tamtéž, s. 19).

Požadavky přicházející $s$ uvedenou novelou zákona znamenaly od zárí 2016 a nadále znamenají pro mnohé školy řadu vnějších i vnitřních změn. Pedagogické procesy a jejich podmínky jsou tím, co podstatným způsobem formuje zkušenost dítěte, jsou bezprostředními podmínkami pro rozvoj osobnosti dítěte a současně prostředím pro naplnění idejí společného vzdělávání, jehož inkluzivní strategie se týkají $\mathrm{v}$ současnosti $\mathrm{v}$ předškolním vzdělávání nově dvouletých dětí, povinného předškolního vzdělávání pětiletých dětí a začleňování dětí $s$ výraznými překážkami v učení, které nemohou bez pomoci samy př́konat.

\section{Metodologické ZÁZEMí VÝZKUMNÉHO ŠETŘENÍ}

Výzkum vycházel z kvalitativního rámce $s$ designem zakotvené teorie, měl zjištující charakter a byl založen na induktivním přístupu ke sběru i vyhodnocení dat. Byl řízen výzkumnou otázkou: Reflektují pedagogové proměny v pedagogických procesech a jejich podmínkách $v$ práci své MŠ po zavedení společného vzdělávání? Konkretizovali jsme ji do dvou obsahových jader: (1) jak pedagogové MŠ reflektují samotný požadavek na zavedení společ- ného vzdělávání, jaké zkušenosti s ním mají a jak se odrážejí v jejich názorech; (2) jak své zkušenosti promítají do své práce. Zdrojem dat byly subjektivní reflexe pedagogů zaměřené na vlastní práci, protože jako takové vycházejí především z profesního rozhodování a jednání, které je generováno podmínkami, a současně jsou podhoubím pro vznik názorů.

Sběr dat probíhal metodou polostrukturovaného rozhovoru. Výzkumný záměr byl operacionalizován do následujících otázek, na které se vázala témata rozhovoru: (1) Jaká byla dosavadní zkušenost $M S ̌ s$ s různorodostí dětí? (2) Ovlivnila dosavadní zkušenost MŠ potřebu něco měnit? (3) $O$ jaký typ případných změn se jednalo? (4) Které podmínky podle respondentů podporují a které limitují pedagogické procesy souladné s konceptem společného vzdělávání a s konceptem osobnostně rozvíjejícího vzdělávání?

Vlastní rozhovor zahrnoval tři tematické oblasti: (1) proměny pedagogických procesů při činnostech v MŠ, včetně plánování a vyhodnocování; (2) reálné podmínky pro společné vzdělávání; (3) výhled procesů a podmínek v souvislosti s vlastní školou.

Strukturu rozhovoru tvořila páteřní otázka pro každou tematickou oblast a konkretizační otázky, které ji měly doplňovat nebo rozšiřovat a svou formulací respektovat myšlení pedagogů MŠ. Otázky byly následující: (1) Pro oblast pedagogických procesů: Jak u vás přihlížíte $\mathrm{k}$ tomu, že jsou ve trrídě nebo 
oddělení děti různě rozvinuté $\mathrm{a} z$ různých kulturních prostředí? (2) Pro oblast podmínek ke společnému vzdělávání: $\mathrm{V}$ čem vidíte pozitiva a negativa, když jsou ve škole různé děti? (3) Pro oblast výhledu v souvislosti s vlastní školou: Co byste do budoucna zachovali, co byste potřebovali dělat jinak?

Pro potvrzení kvality metody jsme využili dva postupy. Prvým jsme se zaměřili na obsahovou validitu. Při běžném, necíleném profesním pobytu v prostředí mateřských škol jsme vygenerovali tř̀i teze odrážející opakované názory pedagogů $\mathrm{v}$ souvislosti se společným vzděláváním. Předložili jsme je $\mathrm{k}$ písemnému vyjádření 30 pedagogům MŠ získaným dostupným výběrem. Tento počet jsme na základě zkušeností z praxe považovali za nasycený. Výpovědi nás orientovaly při kladení otázek ve výzkumném rozhovoru, zároveň nám umožnily uvažovat nad přijatelnou úrovní validity metody, jakmile jsme je porovnali se získanými daty a zjistili shodu. Druhý postup byl zaměřen na reliabilitu. Ve dvou MŠ nezahrnutých do výzkumného vzorku jsme provedli opakované šetření stejným postupem, ale jiným zaškoleným tazatelem. Poprvé proběhlo na začátku, podruhé $\mathrm{v}$ závěru sběru dat. Analyzovaná data potvrdila, že podstata získaných poznatků zůstávala stejná, odpovědi po několika měsících původní údaje jen prohlubovaly nebo rozšiřovaly.

Výzkumný vzorek byl vytvořen záměrným výběrem soustředěným na částečně odlišné lokality. Zahrnoval celkem
20 státních MŠ. Deset MŠ bylo z Prahy a byly vybírány proporčně z centrálních i okrajových částí a současně z lokalit s různým typem bydlení (sídliš̌tě, rodinné domy, hraniční oblasti města $s$ ještě spíše venkovským charakterem). Deset MŠ bylo z Jihočeského kraje, pět městských a pět venkovských. V rámci tohoto počtu byly záměrně voleny i MŠ s výraznější profilací (zaměřené na nadané děti nebo na děti se SVP, na environmentální výchovu, s alternativními nebo inovativními postupy apod.). Tazatelé vždy prostudovali školní vzdělávací program (dále ŠVP). V každé MŠ byly vedeny dva rozhovory. Jeden $s$ ředitelkou nebo pověrenou učitelkou, měla-li MŠ společné vedení se ŽS̆, druhý se skupinou většinou dvou učitelek doplněnou př́padně ještě o asistentku pedagoga $\mathrm{v}$ závislosti na velikosti a složení týmu MŠ. Celkový počet činil 20 respondentů z vedení a 46 pedagogů včetně šesti asistentů pedagoga, celkem 66 respondentů. Participanti byli seznámeni súčelem výzkumu a vyjádřili se zpracováním dat souhlas. Jejich výpovědi byly anonymizovány.

Při zpracování dat byla analyzovanou jednotkou MŠ. Základní metodou bylo otevřené kódování, jehož výsledkem byla kategorizace klíčových témat, z nichž jsme sestavili závaznou strukturu pro zpracování dat každé z 20 MŠ: (1) východisková předchozí zkušenost; (2) vize školy a její sdílení; (3) učitelův pohled na výuku v procesech společného vzdělávání; (4) podmínky - příznivé, nepř́íznivé (včetně asistenta pedagoga). Druhou úrovní zpracování bylo 
axiální kódování zjištěných témat, které vytvořilo kategorie názory, procesy, podmínky souhlasné se sledovanými oblastmi šetření a tvořící osu pro 20 dílčích případových studií MŠ. Následně byla zpracována hromadná prrípadová studie dotčených MŠ ve shodné struktuře: (1) názory vedení a pedagogického týmu a vnímané ovlivňující podmínky; (2) pedagogické procesy a jejich organizace při péči o děti a vnímané podmínky; (3) podmínky pro pedagogické procesy reflektované ve svém celku jako př́znivé nebo limitující.

\section{VÝZKUMNÁ ZJIŠTĚNÍ:}

\section{PEDAGOGICKÉ PROCESY A JEJICH PODMÍNKY VE SPOLEČNÉM \\ VZDĚLÁVÁNÍ V MATEŘSKÉ ŠKOLE}

Získaná data prezentujeme za prvé v přehledových tabulkách, které jsou výsledkem analytického zpracování dat na základě hromadné př́ípadové studie. Respektují sledovanou strukturu, variovanou do následujících položek: (1) podmínky v rovině názorů (viz tab. 1 a 2); (2) podmínky v rovině vnějších okolností (viz tab. 3); (3) pedagogické procesy (viz tab. 4-8). Podstatná sdělení jsou uspořádána ve vztahu mezi vyjádřeným názorem na podstatný jev a jeho vnímanou podmíněností. $\mathrm{Za}$ druhé prezentujeme model MŠ, která implementuje společné vzdělávání (4). Opírá se nejen o získaná data, ale i o výchozí teoretické koncepty a znalost prostředí MŠ. Jeho realizovatelnost a funkčnost pro společné vzdělávání je $\mathrm{v}$ souladu $s$ daty.

\section{Podmínky $\mathrm{v}$ rovině názorů pedagogů $M \check{S}$}

Vstřícné názory respondentů jsou $\mathrm{v}$ zásadě podmiňovány dostatečnou délkou zkušenosti s dítětem, které vyžaduje více individuální péče a specifičtější postupy (tab. 1). Déledobá zkušenost má vliv na ověření, že péče o takové dítě v prostředí $M S ̌$ je zvládnutelná a že pedagogové mají dostatečné znalosti a dovednosti. Výsledkem je subjektivní pocit lepší připravenosti u pedagogů i na děti $s$ výraznější odlišností potřeb, byt mohou být odlišného charakteru, než je dosavadní zkušenost. Je dán mimo jiné i tím, že si zajistí podporu odborníků pro práci s takto potřebnými dětmi, aniž by byla výrazněji narušena práce se všemi dětmi ve třídě nebo škole. Důvodem negativního názoru na inkluzi dvouletých dětí je ohled na děti samotné. Děti takto nízkého věku mají ještě silnou potřebu být co nejdéle $s$ jednou pečující osobou. Odmítavé názory na společné vzdělávání plynou ze dvou typů zkušenosti: (1) Zkušenost s dětmi se SVP je malá nebo žádná. (2) Především speciální pedagogové s dlouhodobou zkušeností jen $s$ určitou kvalitou SVP, především s vývojovou dysfázií, s lehčími formami PAS, prŕpadně s poruchami chování, jsou přesvědčeni, že tyto děti potřebují jiný čas, jiné př́stupy, postupy a činnosti, aby mohly být dobře rozvíjeny. Na výraznější projevy SVP se necítí připraveni. 
Tab. 1 Posuzovací členění

\begin{tabular}{|l|l|l|l|}
\hline $\begin{array}{l}\text { Vstř́cné názory na } \\
\text { společné vzdělávání }\end{array}$ & Konkretizace & $\begin{array}{l}\text { Odmítavé názory na } \\
\text { společné vzdělávání }\end{array}$ & Konkretizace \\
\hline $\begin{array}{l}\text { Dostatečně dlouhá } \\
\text { zkušenost s dítětem } \\
\text { vyžadujícím speciálnější } \\
\text { postupy }\end{array}$ & $\begin{array}{l}\text { V minimálním } \\
\text { rozsahu 4-5 let }\end{array}$ & $\begin{array}{l}\text { K věkové inkluzi } \\
\text { dvouletých dětí }\end{array}$ & $\begin{array}{l}\text { Potřeby těchto dětí jsou } \\
\text { výrazně odlišné od věkové } \\
\text { skupiny 3-5(6)letých }\end{array}$ \\
\cline { 2 - 4 } & $\begin{array}{l}\text { K inkluzi dětí s velmi } \\
\text { výraznými SVP }\end{array}$ & $\begin{array}{l}\text { Potřebují speciální typ } \\
\text { podpory a individuálnější } \\
\text { péči (dítě by mělo být při- } \\
\text { pravováno ve speciálním } \\
\text { zařízení) }\end{array}$ \\
\hline $\begin{array}{l}\text { Dostatečně pestrá } \\
\text { zkušenost }\end{array}$ & $\begin{array}{l}\text { Různé typy } \\
\text { speciálních } \\
\text { vzdélávacích } \\
\text { potřeb dětí }\end{array}$ & $\begin{array}{l}\text { Zkušenost pedagogů je } \\
\text { malá nebo žádná }\end{array}$ & $\begin{array}{l}\text { Pocit nepř́ipravenosti } \\
\text { k péči o děti se SVP }\end{array}$ \\
\cline { 2 - 4 } & $\begin{array}{l}\text { Dlouhodobá zkušenost } \\
\text { speciálních pedagogů }\end{array}$ & $\begin{array}{l}\text { Děti se SVP potřebují spe- } \\
\text { ciální postupy, čas, režim }\end{array}$ \\
\hline
\end{tabular}

Tab. 2 Obsahové členění

\begin{tabular}{|c|c|}
\hline Kategorie & Popis \\
\hline Věková heterogenita & $\begin{array}{l}\text { Nezačleňovat dvouleté děti } \\
\text { Spíše kladný postoj k věkově heterogenním skupinám } \\
\text { Potřeba vyčlenit předškoláky }\end{array}$ \\
\hline $\begin{array}{l}\text { Výrazné SVP a lehké } \\
\text { mentální postižení }\end{array}$ & $\begin{array}{l}\text { V běžné třídě s výraznou pomocí asistenta lze mít tyto děti } \\
\text { Ve speciální třídě se speciálním pedagogem a asistentem - zachovat, } \\
\text { jsou dovednosti, jak s dětmi pracovat } \\
\text { Negativní zkušenost se speciálními třídami - nepřipravenost pedagogů } \\
\text { na velmi výrazné SVP - nelze přijímat tyto děti }\end{array}$ \\
\hline $\begin{array}{l}\text { Děti s odlišným mateř- } \\
\text { ským jazykem }\end{array}$ & $\begin{array}{l}\text { Přijímají ve všech MŠ } \\
\text { Je-li malá zkušenost, vzniká obava, že se nedomluví s rodinou }\end{array}$ \\
\hline Děti s PAS ${ }^{2}$ & Kladný postoj, nejsou-li projevy PAS příliš rušivé pro ostatní děti \\
\hline Děti nadané & $\begin{array}{l}\text { Kladný postoj: } \\
\text { - MŠ s rozvinutou diferenciací a individualizací } \\
\text { - MŠ se ŠVP cíleně nabízeným i nadaným dětem } \\
\text { Neutrální postoj: } \\
\text { - MŠ, které nadané neznají nebo nerozpoznali }\end{array}$ \\
\hline $\begin{array}{l}\text { Děti ze sociálně znevý- } \\
\text { hodněného prostředí }\end{array}$ & $\begin{array}{l}\text { Kladný postoj, ALE problém: } \\
\text { - když je více dětí ze sociálně vyloučených lokalit pohromadě } \\
\text { - když nespolupracující rodinu musí nahradit pomoc dalších subjektů } \\
\text { mimo MŠ }\end{array}$ \\
\hline
\end{tabular}

${ }^{2}$ Poruchy autistického spektra 
Nenalezli jsme nezúčastněné vyjádření, což svědčí pro fakt, že pedagogové na společné vzdělávání reagují a svůj přístup $\mathrm{k}$ němu si zdůvodňují. Rozhodující je osobní prímá zkušenost potvrzující nebo vyvracející jistotu pedagogů v tom, že by péči o děti se SVP zvládli. Názory tedy nejsou ovlivňovány hodnotově, ve smyslu nesouhlasu s konceptem společného vzdělávání, ale zkušeností posuzovanou vědomím, že je třeba, aby o tyto děti bylo postaráno co nejlépe.

Názor na věkovou heterogenitu $\mathrm{v}$ dětské skupině je u většiny respondentů spíše kladný (tab. 2). V některých MŠ v našem vzorku bylo však zavádění heterogenních tříd stále na úrovni experimentu, který prosazuje vedení a který ne vždy přijímá celý tým. Pokud MŠ organizuje vzdělávání svých pedagogů a využívá některý $\mathrm{z}$ programů, který ukazuje, jak diferencovat a individualizovat činnosti, pak je postoj $\mathrm{k}$ věkové heterogenitě kladný. Věkově heterogenní třídy umožní nabízet dítěti činnosti $s$ ohledem na úroveň jeho mentálního a psychomotorického vývoje více než $s$ ohledem na to, co by ve svém věku mělo zvládat. Tento přístup je funkční i pro děti do 3. stupně přiznané pedagogické podpory a pro děti ze sociálně znevýhodněného prostředí. Při větším počtu těchto dětí a při současné malé spolupráci s rodinou je navíc zapotřebí vyhledávat pomoc dalších neziskových organizací, které spolupráci s rodinou zprostředkují. Podobně je tomu u dětí $s$ odlišným mateřským jazykem, $v$ jejich př́ípadě se MŠ obrací na tlumočníky a překladatele opět mimo svůj vlastní tým. Pro nadané děti je situace stále různá. $\mathrm{V}$ některých $\mathrm{MŠ}$ je pravděpodobně nerozpoznají, v jiných se jim snaží nabízet rozvíjející činnosti a pečovat o jejich socializaci v heterogenních třídách. Nejlepší péče se snad dá očekávat v MŠ, které deklarují, že pro tyto děti mají speciální postupy, vyhledávají je a informují jejich rodiny.

Pokud byly v MŠ speciální třídy a po zavedení společného vzdělávání se otevřely pro děti $s$ výraznými SVP (zejména lehké mentální postižení, výrazné projevy PAS a další psychiatrické odlišnosti), získávají pedagogové MŠ, jak už jsme uvedli výše, spíše negativní zkušenost, protože ty to potřeby dětí vyžadují hlubší a konkrétnější vzdělání, než jim dosud stačilo pro vývojové odchylky typu vývojová dysfázie a poruchy chování. V jedné z monitorovaných škol přetrvává pocit, že neumějí s dětmi se SVP pracovat, že to ani není jejich odbornost. $S$ dětmi pracují spíše intuitivně, snaží se je motivovat a využívat pomoci ostatních dětí. Individualizovat podle nich znamená vzít si dítě stranou a pracovat s ním podle doporučení poradny, fakticky ho tak vyčleňují. Domnívají se, že společné vzdělávání může negativně ovlivňovat vztahy mezi dětmi. Na př́íkladu této MŠ se potvrzuje nutnost zaškolování pedagogů v dovednostech práce $s$ různorodou tř́dou.

Co se týče předškoláků, nejsou zpravidla vyčleňováni právě tam, kde se důsledně pracuje s variabilitou činností co do obtížnosti, rozsahu i metody, kde se 
takto práce s dětmi diferencuje a individualizuje jako přirozená zkušenost pedagogů i dětí. Ve většině př́ípadů se ale ukazuje potřeba vyčleňovat předškoláky v rámci jejich př́ípravy na školu do samostatných skupin pracujících ve vymezeném čase $\mathrm{v}$ denním režimu nebo do samostatných tříd $s$ režimem tuto přípravu zohledňujícím.

Pokud jsou v MŠ i dvouleté děti, jsou $\mathrm{v}$ důsledku výrazně jiných potřeb častěji vyčleňovány do samostatné skupiny s chůvami.

\section{Podmínky $v$ rovině vnějších okolností práce MŠ jako instituce}

Vnější podmínky pro práci $M S ̌$ (kromě výzkumem neřešených finančních podmínek) lze $\mathrm{v}$ souvislosti se společným vzděláváním rozdělit do tří ovlivňujících skupin faktorů (tab. 3): (1) spolupráce $s$ rodinou, (2) spolupráce s odborníky mimo tým MŠ, (3) počet dospělých na počet dětí a s tím související počet dětí ve skupině/třídè. Vysoký počet dětí ve třídě je výrazně limitující okolností pro osobnostně rozvíjející přístup i pro společné vzdělávání. Nejsou-li tyto tři faktory nastaveny př́iznivě, výrazně ztěžují práci MŠ v jakémkoli ohledu, tedy i v ohledu ke společnému vzdělávání.

\section{Pedagogické procesy}

O potřebě změny a o její konkrétní podobě rozhoduje př́tomnost nebo neprrítomnost předchozí zkušenosti $s$ variabilitou potřeb dětí $\mathrm{v}$ různých situacích (tab. 4). Organizační změny se týkají

Tab. 3 Vnější okolnosti práce MŠ

\begin{tabular}{|c|c|c|}
\hline Kategorie & Podporující působení & Limitující působení \\
\hline $\begin{array}{l}\text { Počet dětí } \\
\text { ve třídě }\end{array}$ & Do 24 dětí & $\begin{array}{l}25 \text { a více dětí, nedostatečně včasná reakce } \\
\text { na snižování počtu dětí pro projevení } \\
\text { a následnou diagnostiku SVP }\end{array}$ \\
\hline $\begin{array}{l}\text { Počet dospělých } \\
\text { ve třídě }\end{array}$ & $\begin{array}{l}\text { Celodenní přítomnost asistentů } \\
\text { pedagoga, párová výuka v době } \\
\text { řízených činností }\end{array}$ & $\begin{array}{l}\text { Malý počet dospělých v určitých částech } \\
\text { denního režimu, málo asistentů pedagoga }\end{array}$ \\
\hline $\begin{array}{l}\text { Spolupráce } \\
\text { s rodinou dítěte }\end{array}$ & $\begin{array}{l}\text { Spolupracující rodina, poučená } \\
\text { v príipadě dětí se SVP }\end{array}$ & $\begin{array}{l}\text { Nespolupracující rodina, rodina bez zku- } \\
\text { šeností se SVP jejich dítěte, nep̌ripouštějí- } \\
\text { cí si SVP svého dítěte, jazykové překážky }\end{array}$ \\
\hline $\begin{array}{l}\text { Spolupráce } \\
\text { s odborníky } \\
\text { (PPP } \text { PPC }^{4}, \mathrm{SP}^{4} \\
\text { apod.) }\end{array}$ & $\begin{array}{l}\text { Dobrá spolupráce } \\
\text { Schopnost převést diagnostické } \\
\text { údaje do pedagogických postupů } \\
\text { srozumitelných učiteli }\end{array}$ & $\begin{array}{l}\text { Nejsou členy týmu MŠ } \\
\text { Malý počet zaměstnanců vzhledem } \\
\text { k potřebám diagnostiky a podpory dětí }\end{array}$ \\
\hline
\end{tabular}

${ }^{3}$ Pedagogicko-psychologická poradna

${ }^{4}$ Speciálněpedagogické centrum 
především rozhodování o složení tříd, o vytvoření prostor pro společné pobývání a o hraní mimo organizované činnosti (koutky, herny, vyhrazený čas apod.). Vznikají tím př́ležitosti pro setkávání se s různorodostí a pestrostí dětských reakcí, čímž se vytváří prostředí socializace všech dětí v rozměru nabízeném právě společným vzděláváním.

V našem vzorku se objevila jen malá část MŠ, které si ještě nutnost změny nestačily plně uvědomit a reagovat na ni organizačně i v kurikulu. I když je $M S ̌$ z podstaty své práce vstř́ícná vưči společnému vzdělávání, připravenost na nerovnoměrnosti vývoje dítěte sama o sobě nepostačuje na organizaci práce pro společné vzdělávání.

K věkově heterogenním třídám jsme nalezli v zásadě dva prístupy (tab. 5). Prvý předpokládá, že starší děti ve skupině budou pomáhat mladším a mladší se budou rychleji učit od starších. Toto očekávání se ale nenaplní automaticky. I v tomto ohledu děti potřebují vedení a vzory. Někteří pedagogové zjistili, že starší děti (stále ještě nanejvýš pětileté nebo šestileté) neumí nebo nejsou ochotny mladším pomáhat. To je vedlo $\mathrm{k}$ rozhodnutí rozdělit děti na menší, výkonnostně podobné skupiny. Typicky tak vyčlenili děti s odlišným mateřským jazykem, předškoláky a další, kde je vyš-

Tab. 4 Změna organizace

\begin{tabular}{|l|l|}
\hline Situace MŠ & Reakce MŠ \\
\hline $\begin{array}{l}\text { MŠ se zkušeností } s \text { dětmi } \\
\text { se SVP včetně nadaných }\end{array}$ & Změna není nutná, škola je připravena na přijetí různorodých dětí \\
\hline MŠ se speciálními třídami & $\begin{array}{l}\text { Ponechat speciální třídy, postupně podle možností děti integrovat } \\
\text { do běžných tř́d, ve speciálních tř́́dách přijímat a nechávat děti, } \\
\text { které potřebují výraznější individuální péči }\end{array}$ \\
\hline $\begin{array}{l}\text { MŠ bez zkušeností s dětmi } \\
\text { se SVP včetně nadaných }\end{array}$ & $\begin{array}{l}\text { Některé MŠ pocitují potřebu změny a hledají inspiraci, u jiných } \\
\text { není potřeba změny, protože přetrvává minimální zkušenost práce } \\
\text { s dětmi se SVP }\end{array}$ \\
\hline
\end{tabular}

Tab. 5 Organizace tříd/skupin

\begin{tabular}{|l|l|}
\hline Situace MŠ & Reakce MŠ \\
\hline $\begin{array}{l}\text { Principiálně diferencovaný } \\
\text { prístup k činnostem všech } \\
\text { dětí }\end{array}$ & $\begin{array}{l}\text { Předem promyšlená př́íprava různorodých činností, které mohou } \\
\text { děti vykonávat v individuálním tempu } \\
\text { Vyhovuje heterogenní trída - potřeba vzdělávání pedagogů v metodách } \\
\text { diferenciace činností a potřeba cílené spolupráce pedagogú }\end{array}$ \\
\hline $\begin{array}{l}\text { Principiálně společná práce } \\
\text { všech dětí }\end{array}$ & $\begin{array}{l}\text { Všechny děti dělají všechny činnosti společně, v př́ípadě potřeby } \\
\text { větši podpory konkrétního dítěte pedagogové reagují individuální } \\
\text { pomocí a nabídkami }\end{array}$ \\
\hline
\end{tabular}


Tab. 6 Koncepce práce

\begin{tabular}{|l|l|}
\hline Situace MŠ & Reakce MŠ \\
\hline $\begin{array}{l}\text { MŠ s dostatečnou } \\
\text { artikulací koncepce }\end{array}$ & $\begin{array}{l}\text { Koncepce práce je živá, průběžně vyjasňovaná a sdílená } \\
\text { Koncepce práce se promítá do veškeré činnosti instituce } \\
\text { Dostatečné vzdělání vedení a pedagogú školy }\end{array}$ \\
\hline $\begin{array}{l}\text { MŠ se speciálním } \\
\text { programem }\end{array}$ & $\begin{array}{l}\text { Například program waldorfský, Začít spolu, církevní školy: } \\
\text { zřetelně vystupuje hodnotová orientace na přijímání různorodosti } \\
\text { jako pozitivní hodnoty }\end{array}$ \\
\hline $\begin{array}{l}\text { MŠ bez dostatečné } \\
\text { artikulace koncepce }\end{array}$ & $\begin{array}{l}\text { Nepřipravenost na výraznější projevy různorodosti. Čekání } \\
\text { na empirickou zkušenost, zda dovedou na potřeby dětí se SVP } \\
\text { reagovat. Vyšší potřeba pomoci od odborníků. }\end{array}$ \\
\hline
\end{tabular}

ší potřeba individualizace. Druhý z přístupů usiluje o takové prostředí, kde se děti postupně učí pracovat $s$ možností volby. Dospělí i děti vidí a uvědomují si, že každý pracuje jinak kvůli věku nebo svým možnostem a potřebám. Současně pedagogové mají na děti, které potřebují individuálnější péči, více prostoru. I v tomto bodě se ukazuje potřeba menších než osmadvacetičlenných skupin dětí a více vzdělaných pedagogů $\mathrm{k}$ nim.

Přesvědčení o tom, že děti mají dělat vše společně, vede $\mathrm{k}$ hledání, jak různé třídy propojovat, a naopak vnitřně dělit. $\mathrm{K}$ individuální práci se přechází, když pro dítě není možná práce společná. Tyto př́klady ukazují na uvažování nad tím, jak i organizačně $\mathrm{v}$ určitém aspektu sjednocovat a $\mathrm{v}$ určitém aspektu diferencovat.

Významný vliv na kvalitu společného vzdělávání v MŠ, jakož i na její práci samotnou má vyjasněná a sdílená koncepce (tab. 6). Důkazy poskytly MŠ, jejichž program je cíleně hodnotově vymezen, např̀. MŠ s programem wal- dorfské pedagogiky, s programem Začít spolu nebo se zaměřením na křestanské hodnoty u MŠ církevních. K nim lze přriřadit také malé venkovské $M S ̌$, které nemusí vyjadřovat specifičnost hodnotové orientace svého ŠVP, ale jejich klima se bližži klimatu v rodině, dětské skupiny jsou malé, rodiny jsou v těsnější vazbě na MŠ, než jak tomu bývá ve velkých městech. Tyto typy MŠ zakládají vzdělávání svých pedagogů už v koncepci ŠVP. Prostředí pro přijímání rozdílností a různorodosti je připravováno už předem a hodnotově zdůrazňováno právě pro danou MŠ. Koncepce je živá a žitá, udržovaná vedením školy, které vytváří př́ležitosti pro její sdílení a rozvíjení podle reflektovaných zkušeností. Není-li základní princip artikulován a sdílen zřetelně, dostává se MŠ do situace, kdy spíše reaguje, než se připravuje, teprve následně hledá cesty, jak situace řešit a dítě podporovat. Tam, kde není předem vyjasněna teoretická příprava, cítí se školy spíše na společné vzdělávání neprripraveny. I zde je tedy prostor pro 
průběžné vzdělávání pedagogů, ale jako týmů celé školy. K tomuto přístupu se blíží i MŠ, které se principiálně orientují na estetické a environmentální hodnoty. Vidí ve společném vzdělávání velký potenciál, protože ve společných prožitkových činnostech se děti lépe poznávají. Jiným př́kladem je $M \breve{S}$, která se cíleně orientuje na zapojování různých dětí do péče o zvířata. Tato činnost je sjednocující, socializující a zároveň rozvíjí osobnost dítěte.

Klima je jedním z klíčových aspektů pozadí úspěšné realizace pedagogických procesů ve společném vzdělávání (tab. 7). Musí respektovat specifické potřeby dětí tohoto věku, které harmonizují v prvé řadě jejich sociální a emocionální rozvoj. Předpokladem je bezpodmínečné přijetí dítěte, vstřícná komunikace ze strany dospělých a pocit bezpečí ve všech situacích a činnostech, se kterými se dítě v MŠ setkává. Součástí budování takového pocitu dítěte je spolupráce s rodinou a podnětnost prostředí i nabízených činností. Tomu pomáhá profesní i lidská provázanost všech pedagogů i nepedagogických pracovníků v MŠ.

Pro pětileté děti je stále ještě přirozená a relativně výrazná nerovnoměrnost jejich vývoje. Tím, že je MŠ $\mathrm{v}$ současnosti odpovědná $\mathrm{v}$ povinném předškolním vzdělávání pětiletých za jejich př́ípravu na školu (tab. 8), snaží se

Tab. 7 Péče o klima

\begin{tabular}{|l|l|}
\hline Situace MŠ & Reakce MŠ \\
\hline $\begin{array}{l}\text { Podstatou práce MŠ je } \\
\text { vyhovět potřebám daného } \\
\text { věku, zejména rozvíjení } \\
\text { sociálního a emocionálního } \\
\text { aspektu osobnosti díť̌te } \\
\text { Spolupráce } s \text { rodinou }\end{array}$ & $\begin{array}{l}\text { Budují podnětné a bezpečné klima. Vstřícná komunikace } \\
\text { Princip přijetí každého dítěte a reakce na jeho aktuální situaci } \\
\text { Vytvářet atmosféru podobnou životu v rodině }\end{array}$ \\
\hline $\begin{array}{l}\text { V některých MŠ cílená pečee } \\
\text { o tým pedagogických i ne- } \\
\text { pedagogických pracovníkú }\end{array}$ & $\begin{array}{l}\text { Pomáhá větší provázanost všech v MŠ, společné činnosti a př́ležitosti } \\
\text { k setkávání a sdílení }\end{array}$ \\
\hline
\end{tabular}

Tab. 8 Povinné předškolní vzdělávání

\begin{tabular}{|l|l|}
\hline Situace MŠ & Reakce MŠ \\
\hline $\begin{array}{l}\text { Situace je stejná } \\
\text { pro všechny MŠ }\end{array}$ & $\begin{array}{l}\text { MŠ s věkově homogenními tř́ídami vytvářjí třídu/skupinu } \\
\text { předškoláků }\end{array}$ \\
\cline { 2 - 2 } & $\begin{array}{l}\text { MŠ s věkově heterogenními třídami: } \\
\text { - bud' diferencují stále všechny činnosti } \\
\text { - nebo po část dne vyčleňují skupinu předškoláků pro cílené, } \\
\text { především kognitivní a psychomotorické činnosti }\end{array}$ \\
\hline
\end{tabular}


pedagogové nerovnoměrnosti ve vývoji vyrovnávat, soustředí se na procvičování těch oblastí, ve kterých je dítě slabší z hlediska předpokládaných požadavků na připravenost dítěte na základní školu. Tato situace akcentuje v práci MŠ $s$ pětiletými více dorovnávání kognitivních a psychomotorických dovedností, což vede $\mathrm{k}$ časnějšímu vyčleňování pětiletých z heterogenní skupiny. Je třeba také brát $\mathrm{v}$ úvahu, že pětileté děti, které přicházejí do $M S ̌$ z rodiny nebo jiné dětské skupiny, také potřebují respekt $\mathrm{k}$ individuálně dlouhé adaptaci na nové prostředí a činnosti.

\section{Model fungujícího společného vzdělávání v mateřské škole}

$\mathrm{Na}$ základě zkušeností monitorovaných MŠ, ve kterých se daří nebo spíše daří organizace společného vzdělávání, modelujeme obraz fungování takové MŠ. Je to škola s různými dětmi, s týmem profesionálů vnímajících dítě, otevřených změnám a spolupráci s rodinou a dalšími odborníky, má dostatečně dlouhou a pestrou zkušenost $s$ novou diverzitou a $s$ tím, jak $s$ ní pracovat. Typické motto ŠVP takové školy zní: „Ve společném vzdělávání pedagogové respektují dítě a děti se učí respektovat pravidla a denní režim.“

Co, jak a proč dělají pedagogové, když se jim daří realizovat společné vzdělávání, pracovat $s$ růzností v několikerém významu? Sledujeme typický denní režim a uvažujeme, co je za ním při společném vzdělávání.

\section{Společné porady a komunikace pe-} dagogů: Společné soustředění se na konkrétní děti, aktualizaci obsahu, postupů, pravidel. Pedagogové se domlouvají na aktualizaci ŠVP, tř́ídního programu, individuálních plánů, aby společně rozuměli koncepci a implementaci společného vzdělávání, měli ujasněný program a byli připraveni přijít do třídy a pružně a tvořivě reagovat na jednotlivé děti, autentické situace, aktualizovat pedagogickou diagnostiku.

Příchod a odchod dítěte ze školy: Napojení se na dítě. Pedagogové komunikují s dítětem a rodičem, aby umožnili dítěti a jeho rodiči vyjádřit své nálady a potřeby; aby se napojili na každé dítě, zvláště na děti se specifickými potřeba$\mathrm{mi}$, a to nejen $\mathrm{v}$ adaptačním období.

Volná hra dětí: Facilitace setkávání dětí s růzností při volné hře. Pedagogové připravují pro děti podnětné (ne však přesycené) prostředí, pozorují situaci a děti při hře, zapojují se do hry, aby podněcovali tvořivost dětí a pomohli dítěti, které to potřebuje, komunikovat a začlenit se.

Komunitní kruh: Vytváření bezpečného klimatu. Pedagogové budují pozitivní vztahy mezi dětmi, poskytují individuální pomoc dětem, otevírají nová společná témata, aby se každé dítě cítilo bezpečně; aby se mohlo se soustředit, vyjádřit, naslouchat, dodržet pravidla, osamostatňovat se; aby různé děti měly také společnou zkušenost a mohly s ní dál pracovat.

Řízená činnost (a): Výrazně diferencovaná a individualizovaná činnost. 
Pedagogové diferencují a individualizují cíle, obsahy, postupy, tempo činnosti, aby reagovali na potřeby věku i úroveň rozvoje jednotlivých dětí, na rozdílné zkušenosti, zájmy či výkonnost dětí; aby vytvářeli podmínky i pro zcela individuální práci dítěte $s$ asistentkou nebo učitelkou. Limity se projevují v didaktizované činnosti s dvouletými dětmi.

Ř́zená činnost (b): Činnosti zaměřené na komplexní rozvoj osobnosti dítěte. Pedagogové plánují a řídí různé druhy učení dětí, aby otevírali potenciality rozvoje každého dítěte a umožnili zažívat úspěch každému dítěti. Limity se projevují při velkém počtu dětí a nedostatku odborného personálu.

Společné stolování, pobyt venku: Setkávání s růzností a s pravidly v dalších prostředích. Pedagogové vytvářejí další př́ležitosti pro komunikaci a hru dětí, aby rozvíjeli a zároveň slad’ovali základní životní návyky dětí z různých prostředí; aby mohli pozorovat děti v jiných situacích a individuálně se věnovat jednotlivým dětem.

Činnosti předškoláků: Specifické činnosti předškoláků. Pedagogové v organizaci dne vytvářejí nové př́ležitosti pro skupinovou a individuální činnost předškoláků, aby se mohli zaměřovat na otevírání potencialit i na slabší oblasti jednotlivců, na rozvoj pracovních návyků a samostatnosti; aby mohli uspokojovat vzdělávací i adaptační, socializační potřeby nově příchozích pětiletých dětí.

Společná setkávání $s$ rodinami a napříč třídami: $M S ̌$ doplňuje rodin- nou výchovu. Pedagogové kladou důraz na vytváření pravidelných př́ležitostí (dílny, slavnosti) pro přirozenou komunikaci a setkávání pedagogů, personálu, dětí a jejich rodičů, aby podporovali společenství, kde různost je přirozená, přijímaná, vítaná a kde se všichni mohou také učit něčemu novému.

Propojování mateřské a primární školy: Od role předškoláka k roli školáka. Pedagogové přemýšlejí o funkčních formách komunikace se základními školami, aby připravovali děti na změnu jejich role i vzdělávacího prostředí; aby podpořili a ošetřovali kontinuitu rozvoje dětí (otázka předávání portfolií dětí).

\section{ZÁVĚR - OBLASTI DOPORUČENÍ \\ PRO VZDĚLÁVACÍ POLITIKU}

Zjištující výzkum potvrdil, že respektování teoretických poznatků, na jejichž základě byl vytvořen model osobnostně rozvíjejícího vzdělávání a vysloven požadavek společného vzdělávání, vede za určitých podmínek $\mathrm{k}$ dobré implementaci společného vzdělávání v prostředí MŠ.

Přestože prezentace údajů zachycovala pedagogické procesy a jejich podmínky především uvnitř $M S$, dovolují zjištěné údaje extrapolovat vnější podmínky nezbytné pro dobrou práci MŠ. $V$ rámci těchto vnějších podmínek identifikujeme pět oblastí, kterým by měla vzdělávací politika věnovat pozornost:

(1) Podpora orientace na osobnostně rozvíjející přístup př̀i vzdělávání dítěte $\mathrm{v}$ kurikulárních doku- 
mentech. Realizace kurikula, které má na pozadí osobnostně rozvíjející př́stup při péči o každé jednotlivé dítě, musí být přirozeně koherentní v linii RVP PV - ŠVP - třídní tematické plány i plány individuálního rozvoje pro každé dítě, včetně individuálních vzdělávacích, případně výchovných plánů. Funkční plány rozvoje každého jednotlivého dítěte vznikají postupně, na základě delš́ího a průběžného pozorování a kontaktu s dítětem, sdílením mezi pedagogy a ve spolupráci s rodinou. Pro zajištění této koherence je potřeba zajištovat systematickou metodickou podporu vedení i pedagogům MŠ. V kurikulárních dokumentech je třeba nadále podporovat význam sociálně emocionálního rozvoje dítěte, nejen jeho rozvoj kognitivní. Zdůrazněná snaha vyrovnávat $\mathrm{v}$ předškolní př́pravě nerovnosti, především $\mathrm{v}$ kognici a grafomotorice, aby bylo dítě připravené na požadavky základního vzdělávání, může u některých dětí i negativně ovlivnit jejich sociální rozvoj. $\mathrm{Na}$ nerovnoměrnost vývoje u šestiletých (sedmiletých) dětí má být lépe připravena i základní škola a společně s MŠ mají podporovat kontinuitu vývoje každého dítěte.

(2) Vzdělávání pedagogických pracovníků MŠ. Vzdělávání pedagogických pracovníků vyžaduje v první řadě aktualizaci nároků na kvalitu profese pedagoga $M S ̌$ : porozumění specifikům práce $s$ dětmi s výraznými SVP; poznávání kurikula navazující instituce - 1 . stupně základní školy; dovednost diferencovat péči o různé děti nejen $\mathrm{z}$ věkového hlediska, ale také z hlediska dalších významů diverzity; dovednost spolupracovat $s$ dalšími odborníky a rodinami dětí. V pregraduální prípravě to znamená: podporovat profesně orientované studijní programy zaměřené na propojování teorie $s$ praxí a aktualizovaných klíčových teoretických poznatků s rozvojem profesních dovedností diferencovat a individualizovat péči o různé děti $\mathrm{v}$ heterogenních skupinách, ve spolupráci s kvalitními MŠ a jejich pedagogy. Důsledně směřovat k vyššímu zastoupení vysokoškolsky připravených pedagogů $M S ̌$. V dalším vzdělávání to znamená: prosadit kariérní řád podporující celoživotní učení a profesní rozvoj ředitelů a pedagogů MŠ, podporovat účinné obsahy (rovněž nabídky vzdělávání zaměřené na poznávání potřeb dětí se SVP) a formy dalšího vzdělávání a péče o psychohygienu pedagogů (konzultace, supervize, vzdělávání týmů MŠ).

(3) Počet dětí vázaný na počet osob, které o ně mohou pečovat a rozvíjet je. $Z$ výzkumu vyplývá apel za prvé na snížení požadavku na základní počet dětí ve třídě (z 28 na 24 dětí i méně) a za druhé na zvyšování počtu pedagogů, asistentů pedagoga a dalších odborníků, se kterými musejí pedagogové $\mathrm{v}$ případě potřeby spolupracovat.

(4) Spolupráce MŠ s poradenskými pracovišti a dalšími odborníky. Nezbytnost spolupráce pedagogů s dalšími odborníky ve společném vzdělávání je zřejmá. $Z$ toho vychází apel 
na zvyšování počtu odborníků kvalifikovaných pro danou věkovou kategorii dětí, kteří spolupracují s $M S ̌$ a rodinami dětí, nejen speciálních pedagogů a psychologů, ale také sociálních pedagogů, logopedů, tlumočníků a překladatelů, př́padně psychiatrů. Je třeba udržovat, a hlavně průběžně personálně zajištovat sít služeb pro školy a také pro rodiče dětí kvůli dostupnosti rychlých průběžných konzultací.

(5) Podpora rodin, zvláště znevýhodněných. MŠ je počátečním člán- kem vzdělávacího systému, kde se děti setkávají a učí žít společně. Zároveň je třeba $M S ̌$ nadále chápat jako doplněk klíčové rodinné výchovy pro předškolní dítě. Jedněmi z nejohroženějších z hlediska další školní úspěšnosti jsou děti ze sociálně znevýhodněného prostředí a rodiny, ve kterých tyto děti vyrůstají. Zvláště tyto rodiny potřebují vedle fungujícího a dostupného školského systému od MŠ také další fungující informační a podpůrné systémy, programy a péči.

\section{LiteratURA}

Helus, Z. (2009). Ditě v osobnostním pojetí. Obrat k ditěti jako výzva pro učitele i rodiče. Praha: Portál.

Helus, Z. (2012). Společenská krize - důsledky pro pojetí edukace jakožto starosti o člověka. In H. Lukášová et al., Promény pojetí vzděláváni a školního hodnocení. Filozofická východiska a pedagogické souvislosti (s. 7-40). Praha: Asociace waldorfských škol ČR.

Lang, G., \& Berberichová, Ch. (1998). Každé dítě potřebuje speciální prìstup. Praha: Portál.

Opravilová, E. (2013). Obrazy dětství a vzdělávání dětí. In H. Hejlová, E. Opravilová, J. Uhlírová \& N. Bravená, Nahliženi do svèta dètí (s. 7-39). Praha: Pedagogická fakulta UK.

Rámcový vzdělávací program pro předškolni vzděláváni. (2018). Praha: MŠMT. Dostupné z https://www.msmt.cz

Stinken-Rösner, L., Rott, L., Hundertmark, S., Baumann, Th., Menthe, J., Hoffmann, T., ... Abels, S. (2020). Thinking inclusive science education from two perspectives: Inclusive pedagogy and science EDUCATION. RISTAL (Research in Subject-matter Teaching and Learning), 3, 30-45.

Strategie vzdélávací politiky České republiky do roku 2030+ (2020). Praha: MŠMT. Dostupné z https://www.msmt.cz

Šumníková, P., \& Květoňová, L. (2019). Dítě se zrakovým postižením v inkluzivním vzdělávání. In N. Pelcová \& L. Květoňová et al., Stejné a jiné ve filozofické a speciálněpedagogické reflexi. Inkluzivníškola (s. 301-308). Praha: Pedagogická fakulta UK.

Tomková, A., \& Hejlová, H. (2018). Pedagogické procesy v podmínkách společného vzdělávání a jejich výzkum. Slavonic Pedagogic Studies Journal, 7(2), 247-268. 
Tomková, A., Hejlová, H., Procházka, M., \& Najmonová, M. (2020). Spolupráce učitele $s$ dalšimi odborniky v realitě společného vzděláváni. České Budějovice: Pedagogická fakulta JČU.

Toolkit for inclusive early childhood education and care. Providing high quality education and care to all young children. (2020). Brussels: European Commission.

Zákon č. 82/2015 Sb., kterým se méní zákon č. 561/2004 Sb., o predškolním, základním, struednim, vyššim odborném a jiném vzdèláváni (školský zákon), ve znèni pozdějǔsich predpisu.

Zákon č. 561/2004 Sb., o predškolnim, základnim, střednim, vyššim odborném a jiném vzdèláváni (školský zákon), ve znèní pozdějsích predpisü.

PhDr. Helena Hejlová, Ph.D.,

Univerzita Karlova, Pedagogická fakulta, katedra preprimární a primárni pedagogiky;

e-mail: helena.hejlova@pedf.cuni.cz

doc. PhDr. Anna Tomková, Ph.D.,

Akademie múzických umèni v Praze, Divadelni fakulta, katedra výchovné dramatiky;

e-mail:anna.tomkova@damu.cz

\section{HEJLOVÁ, H., TOMKOVÁ, A. From Research on Inclusive Education in Kindergartens - Issues for Educational Policy Makers}

Our research traced the ways in which teaching and teaching conditions in kindergartens have changed because of the introduction of inclusive education in the updated Framework Educational Programme for Preschool Education. The aims of our research were designed to address the needs of educational policy makers and were narrowed down to two areas: (1) the structuring of data into key categories, addressing the experiences, attitudes, opinions, and ideas of kindergarten teachers working in inclusive education; (2) in the interpretation of the data, to highlight areas that are essential for the successful implementation of inclusive education in kindergartens. The starting point of our theoretical approach was the connection between the values that are intrinsic to a personality-orientated concept of education and those that are intrinsic to inclusive education. As a data collection method, we conducted semi-structured interviews. Our sample group consisted of ten kindergartens from Prague and ten from the South Bohemian region. We first processed the data by creating case studies of individual schools, and then we created an overall study. The results are structured into four areas: (1) conditions relating to the attitudes of the kindergarten teachers who were interviewed; (2) conditions relating to external circumstances 
that affect the kindergarten as an institution; (3) pedagogical processes: changes within the organisation of the school, the organisation of classes, the concept of the work, taking care of the classroom climate, the compulsory education of children in the final year of kindergarten; (4) the model of the kindergarten implementing inclusive education. In our conclusions, we consider what conditions the kindergarten needs in order to implement inclusive education successfully. We structure them into five areas of recommendations for educational policy makers: (1) support the personality-orientated concept of education in the curriculum of preschool education; (2) provide education for the pedagogical staff; (3) link the number of children in the class to the number of staff who can care for them and oversee their development; (4) the cooperation of kindergartens with external counselling centres; (5) support for families, especially those who are disadvantaged.

Keywords: preschool education, personality-oriented concept of education, inclusive education, pedagogical processes, qualitative research 